\title{
Methods of sampling benthic invertebrates in lotic habitats: a spatial and temporal evaluation
}

\author{
Métodos de amostragem de invertebrados bentônicos em ambientes lóticos: \\ uma avaliação espacial e temporal
}

\author{
Larissa Lima da Cunha $^{1}$ (D), Maria Ines Bulgari Alves ${ }^{1}$ (D), Erika Ramos Ono ${ }^{1}$ (D) and \\ Virginia Sanches Uieda ${ }^{1,2 *}$
}

\begin{abstract}
${ }^{1}$ Departamento de Zoologia, Instituto de Biociências, Universidade Estadual Paulista - UNESP, Campus de Botucatu, CP 510, CEP 18618-970, Botucatu, SP, Brasil

${ }^{2}$ Volunteer teacher, Departamento de Zoologia, Instituto de Biociências, Universidade Estadual Paulista - UNESP, Campus de Botucatu, CP 510, CEP 18618-970, Botucatu, SP, Brasil *e-mail: vsuieda@gmail.com
\end{abstract}

Cite as: Cunha, L.L. et al. Methods of sampling benthic invertebrates in lotic habitats: a spatial and temporal evaluation. Acta Limnologica Brasiliensia, 2019, vol. 31, e4.

\begin{abstract}
Aim: We compared the effectiveness of two sampling devices, the Surber sampler and the D-frame net, commonly used in the analysis of invertebrate fauna structure in biomonitoring programs. These programs use the response of benthic invertebrates to assess changes in aquatic ecosystems because they respond quickly to spatial and temporal variations. However, the lack of consensus on the best method of sampling the fauna may reduce the quality of these studies. Methods: We evaluated both devices in four structurally different reaches of streams, two in places with preserved riparian vegetation and two occurring in places with many anthropic disturbances. We repeated the analysis at the dry season of two consecutive years. Results: The two samplers were equally effective in analyzing the benthic fauna and sensitive enough to identify spatial and temporal variation in the structure of this fauna, influenced by the presence or absence of riparian vegetation, by the position of the reach with this vegetation (upstream or downstream of the reach without vegetation) and the characteristics of the substrate. Conclusions: The analyzed fauna structure was similar for the two samplers, but we consider the use of Surber more advantageous and effective because it collects a smaller number of individuals, reducing the time of processing and identifying in the laboratory, and allows a better definition of the area sampled.
\end{abstract}

Keywords: D-frame net; surber sampler; quantitative sampling; tropical stream.

Resumo: Objetivo: Comparamos a eficácia de dois dispositivos de amostragem, o amostrador Surber e a Rede-D, comumente utilizados na análise da estrutura da fauna de invertebrados em programas de biomonitoramento. Esses programas utilizam a resposta dos invertebrados bentônicos para avaliar as mudanças nos ecossistemas aquáticos porque respondem rapidamente às variações espaciais e temporais. No entanto, a falta de consenso sobre o melhor método de amostragem da fauna pode reduzir a qualidade desses estudos. Métodos: Avaliamos ambos os dispositivos em quatro trechos estruturalmente diferentes de riachos, dois em locais com vegetação ripária preservada e dois ocorrendo em locais com várias alterações antrópicas. Repetimos a análise na estação seca de dois anos consecutivos. Resultados: Os dois amostradores foram igualmente eficazes na análise da fauna bentônica e sensíveis o suficiente para identificar variaçóes espaciais e temporais na estrutura desta fauna, influenciada pela presença ou ausência de vegetação ripária, pela posição do trecho com essa vegetação (a montante ou jusante do trecho sem vegetação) e pelas características do substrato. Conclusóes: A 
estrutura da fauna analisada foi semelhante para os dois amostradores, mas consideramos o uso do Surber mais vantajoso e efetivo por amostrar um menor número de indivíduos, reduzindo o tempo de processamento e identificaçáo no laboratório, e por permitir uma melhor definiçáo da área amostrada.

Palavras-chave: Rede-D; amostrador Surber; amostragem quantitativa; riacho tropical.

\section{Introduction}

Biomonitoring programs use the response of organisms to assess changes in the environment, whether natural or arising from anthropogenic actions (Buss et al., 2003). In these programs, benthic invertebrates are the most tested and used group because they are good indicators of environmental quality and are found in practically all aquatic habitats (Buss et al., 2003; Mugnai et al., 2011; Siegloch et al., 2014; Buss et al., 2015).

In Brazil, although environmental agencies present suggestions for the use of biomonitoring, the lack of studies on sampling, sorting, identifying and analyzing standards reduces the quality of these methodologies (Buss et al., 2003). The scarcity of resources and qualified professionals in environmental agencies creates difficulties on the establishment of these standards and makes important the support of universities and research centers in the construction of this knowledge (Buss et al., 2003). In Brazil, there is still no consensus about the best model of biomonitoring protocol to apply, due in part to the scarcity of basic knowledge on the structure and functioning of aquatic communities, which greatly influences the choice of the best methodology to be used in these programs (Buss et al., 2003). The two most used samplers are the D-frame aquatic net (kick net) and the Surber sampler, but according to Buss \& Borges (2008) few studies compare the sampling efficiency of these two methodologies.

In addition, the habitat heterogeneity and the seasonal sampling period may influence the results, leading to differences in macroinvertebrate fauna structure (Callanan et al., 2008). Therefore, understanding the efficiency of sampling techniques as well as the possible influence of regional and local factors on the results are of great importance for the improvement of biomonitoring models, necessary for the preservation of water resources in Brazil.

Thus, in the present work the aim was to compare the performance of the Surber and D-frame net samplers, commonly used in studies of stream benthic invertebrates, in the analysis of the structure of this fauna. The comparison was done in four structurally different stream reaches (spatial analysis), sampled in two consecutive years (temporal analysis).

\section{Material and Methods}

\subsection{Study sites}

We developed the study in two third-order streams belonging to the Paranapanema River Basin, located in the State of São Paulo, southeastern Brazil. Two reaches of each stream (Itaúna and Farias streams) were chosen for the study, one with, other without riparian vegetation, respectively called forest and open reaches (Figure 1).

The forest reach of Itaúna stream $\left(23^{\circ} 09^{\prime} 30.8^{\prime \prime} \mathrm{S}\right.$, $\left.48^{\circ} 37^{\prime} 58.5^{\prime \prime} \mathrm{W}\right)$ is inserted in a fragment of semi-deciduous forest, with a rocky margin, bed with a deposit of vegetal debris (leaves, branches and trunks) and with coarse substrate (>16 mm, such as boulder, cobble and coarse gravel). Its open reach is located downstream $\left(23^{\circ} 09^{\prime} 58.6^{\prime \prime} \mathrm{S}\right.$; $48^{\circ} 37^{\prime} 32.9^{\prime} \mathrm{W}$ ), with partially submerged grasses on the banks and bed, and predominance of fine substrate $(<16 \mathrm{~mm}$, such as medium to fine gravel, granule, sand, silt and clay). The two reaches of Itaúna stream also differ in terms of mean depth values (23.1 and $40.4 \mathrm{~cm}$, respectively in forest and open) and width (489 and $196 \mathrm{~cm}$ ).

The forest reach of Farias stream $\left(23^{\circ} 01^{\prime} 9.8^{\prime \prime} \mathrm{S}\right.$, $\left.48^{\circ} 55^{\prime} 38.4^{\prime} \mathrm{W}\right)$ presents a semi-deciduous forest on the right margin and peanut grass (Arachis repens Handro, Fabaceae) on the left bank, interspersed with sparse trees planted for recovery of the native forest, and bed with predominance of fine substrate and with deposits of vegetal debris. Its open reach is located upstream ( $23^{\circ} 01^{\prime} 16.5^{\prime}$ 'S, $\left.48^{\circ} 55^{\prime} 6.3^{\prime \prime W}\right)$, in a place with several anthropic alterations, such as plantation of woody bamboo (Poaceae), margins with peanut grass or exposed soil, a dam located above the reach, and bed with predominance of fine substrate covered by rooted macrophytes (Egeria sp., Hydrocharitaceae). For this stream, the difference between the two reaches in terms of mean depth (52.6 and $43.4 \mathrm{~cm}$, respectively) and width $(2.2$ and $1.7 \mathrm{~cm})$ was not as striking.

\subsection{Sampling}

We sampled the benthic invertebrate fauna in the dry season of two consecutive years (October 2014 and August 2015). In 2014, three months of rainfall below $30 \mathrm{~mm}$ preceded the sampling date, 
although heavy rains occurred in early September, but at least three weeks before collection in October (Figure 2). On the other hand, in 2015, the rainy season presented high rainfall rates (generally above $200 \mathrm{~mm}$ ) and an atypical dry season occurred, with rainfall near or often above $100 \mathrm{~mm}$, with the exception of June and August (Figure 2).

We collected four sampling units with Surber (mesh $250 \mu \mathrm{m}$ and area $\left.900 \mathrm{~cm}^{2}\right)$ and three with D-frame net (mesh $250 \mu \mathrm{m}$ and sampled area $1200 \mathrm{~cm}^{2}$ ),
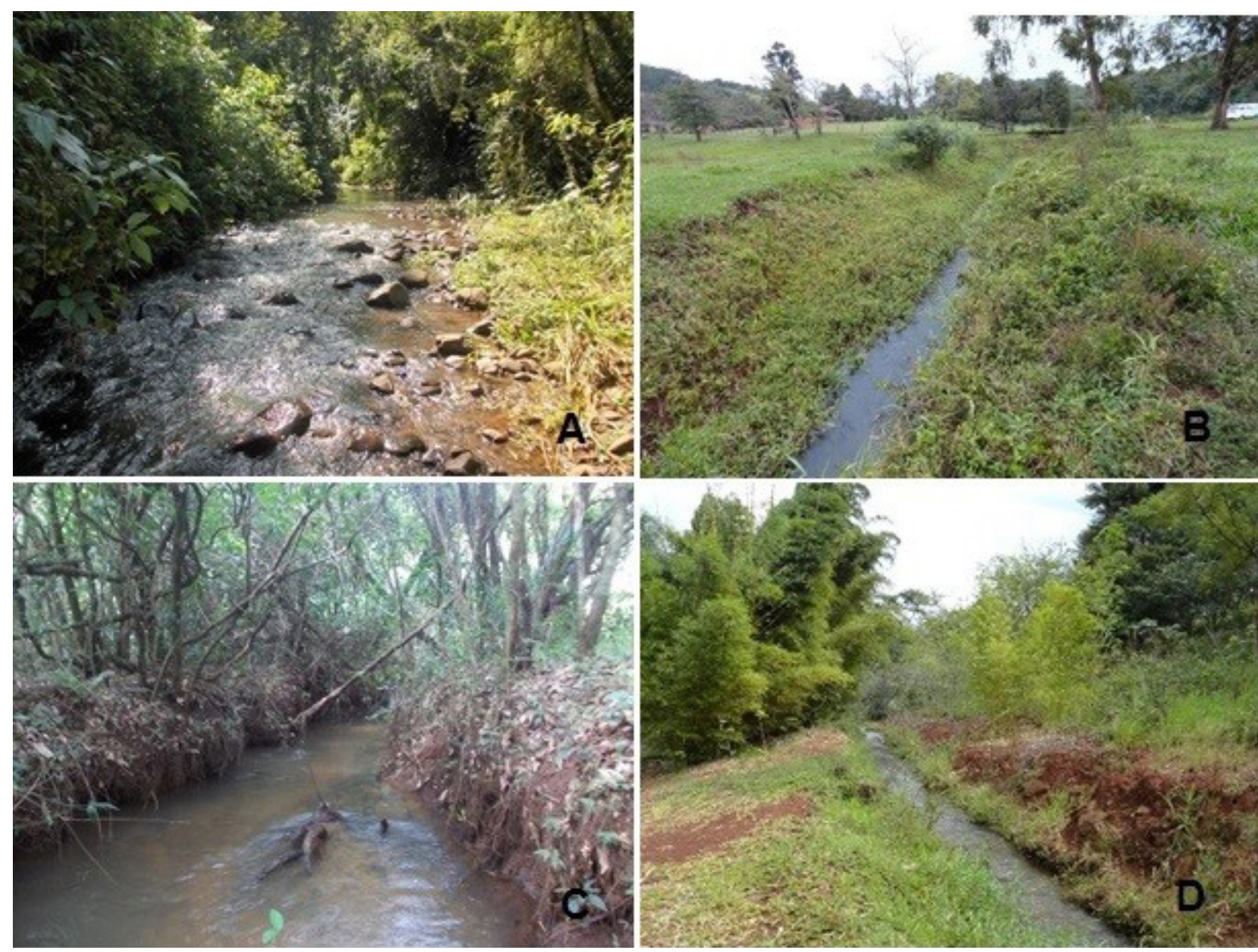

Figure 1. General view of the four study sites, two in Itaúna stream (A- with and B- without riparian vegetation) and two in Farias stream (C- with and B- without riparian vegetation).

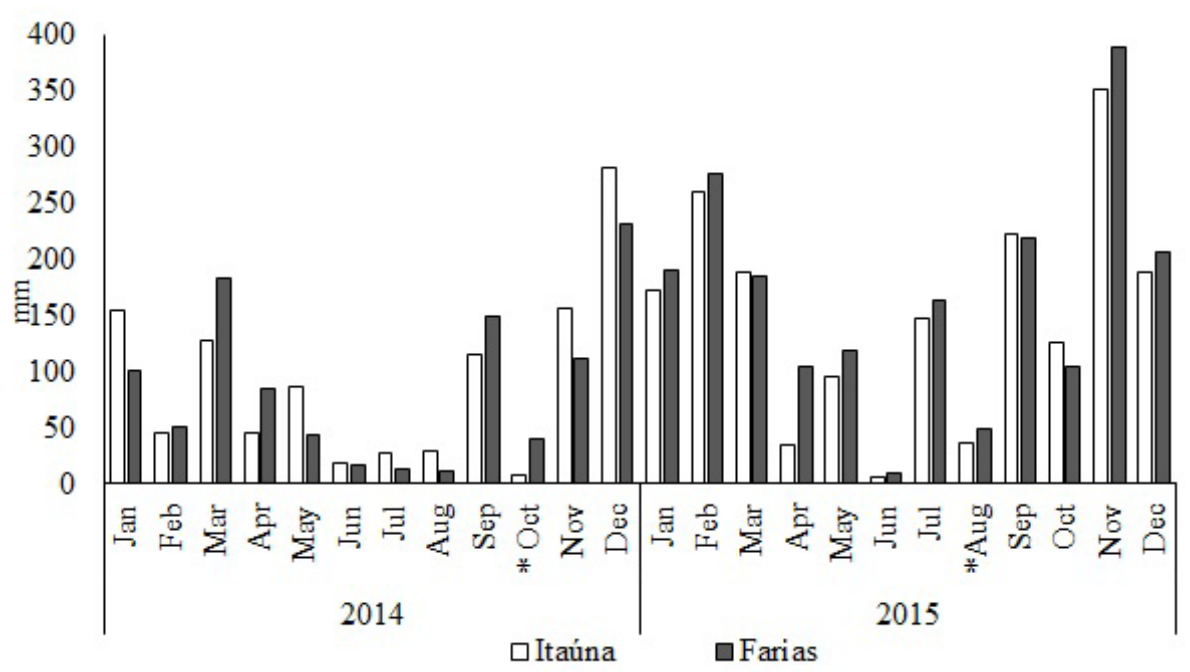

Figure 2. Values of rainfall $(\mathrm{mm})$ measured in the municipalities of Itatinga (Itaúna stream) and Avaré (Farias stream) in the two years in which the study was carried out, being indicated $\left(^{*}\right)$ the two months of collection in the dry season (October 2014 and August 2015). 
distributed along $100 \mathrm{~m}$ of each reach studied. In order to allow the comparison between the samplers, we standardized the collection sites (always in places with moderate current) and the total area sampled considering the sum of sampling units per sampler (3600 $\mathrm{cm}^{2}$ by sampler). We conditioned the samples separately in properly labeled plastic bottles and fixed in $70 \%$ alcohol.

In the laboratory, we floated the samples to separate the invertebrates from the sediment through the density difference, using a sodium chloride solution (200 g. $\left.\mathrm{L}^{-1}\right)$ (Kuhlmann et al., 2012). The organisms found were screened and identified under a stereomicroscope and optical microscope at the lowest possible taxonomic level, with the aid of general identification keys (Pennak, 1978; Dominguez \& Fernández, 2009; Mugnai et al., 2010) and, when necessary, additional literature to identify insects at the genus level.

\subsection{Data analysis}

We performed all statistical analyzes separately by stream, comparing the types of samplers, in relation to reaches (spatial analysis) and years (temporal analysis), using the statistical package
Primer version 6.1.12 \& Permanova + version 1.0.2. The abundance data (sum of sampling units) of the total OTU's identified (Operational Taxonomic Unit) was first transformed in $\log (\mathrm{x}+1)$ and a Bray-Curtis similarity measure was used to create a resemblance matrix. With this matrix, we performed a Hierarchical Clustering analysis (group average) and a Principal Coordinates analysis (PCO) to explore and visualize the similarity between samplers (Surber, D-frame net), across reaches (forest and open) and years $(2014,2015)$.

\section{Results}

In general, the comparison between the samplers showed a higher abundance of invertebrates collected with the D-frame net for both streams (Tables 1 and 2), being in general sampled twice as many individuals with this net. Regarding the richness, the difference between the samplers was not so marked and the percentage of rare OTU's was higher than $60 \%$ in both reaches and streams.

When analyzed the groups of invertebrates sampled in the Itaúna stream, the results obtained with the two samplers were similar. Hexapoda presented the highest relative abundance,

Table 1. Relative abundance (\%) of benthic invertebrates sampled in two reaches of Itaúna stream (O- open, F- forest) in 2014 and 2015, using two samplers (Surber and D-frame net). Data presented for the higher taxonomic groups, for the Hexapoda orders and for the total OTU's sampled (rare $=$ abundance $<1 \%$ ).

\begin{tabular}{|c|c|c|c|c|c|c|c|c|}
\hline \multirow{2}{*}{ HIGHER GROUPS } & \multicolumn{2}{|c|}{$0-2014$} & \multicolumn{2}{|c|}{$0-2015$} & \multicolumn{2}{|c|}{ F-2014 } & \multicolumn{2}{|c|}{ F-2015 } \\
\hline & Surber & D-frame & Surber & D-frame & Surber & D-frame & Surber & D-frame \\
\hline Platyhelminthes & 0.05 & 0.04 & 0.00 & 0.00 & 0.00 & 0.00 & 0.09 & 0.17 \\
\hline Nemertea & 0.55 & 0.00 & 0.00 & 0.19 & 0.00 & 0.01 & 0.19 & 0.08 \\
\hline Mollusca & 3.45 & 4.41 & 0.38 & 0.56 & 0.68 & 1.17 & 0.93 & 0.11 \\
\hline Annelida & 5.34 & 5.68 & 33.27 & 22.57 & 0.29 & 0.10 & 18.01 & 9.88 \\
\hline Nematoda & 0.05 & 0.00 & 0.75 & 0.28 & 0.00 & 0.00 & 0.28 & 0.22 \\
\hline Chelicerata & 11.59 & 17.13 & 1.88 & 3.60 & 1.39 & 2.80 & 2.60 & 6.37 \\
\hline Crustacea & 0.95 & 2.54 & 0.56 & 0.84 & 0.00 & 0.09 & 1.02 & 1.44 \\
\hline Hexapoda & 78.02 & 70.19 & 63.16 & 71.96 & 97.64 & 95.84 & 76.88 & 81.73 \\
\hline \multicolumn{9}{|l|}{ HEXAPODA ORDERS } \\
\hline Collembola & 1.92 & 0.30 & 0.45 & 0.46 & 0.04 & 0.02 & 0.60 & 0.20 \\
\hline Coleoptera & 2.69 & 1.87 & 8.63 & 9.24 & 2.45 & 1.13 & 3.50 & 4.84 \\
\hline Diptera & 75.74 & 73.78 & 53.57 & 59.21 & 56.62 & 40.77 & 28.02 & 29.13 \\
\hline Ephemeroptera & 15.43 & 18.73 & 30.51 & 22.77 & 16.24 & 31.87 & 60.51 & 59.32 \\
\hline Hemiptera & 0.19 & 0.00 & 0.15 & 0.00 & 0.00 & 0.02 & 0.12 & 0.03 \\
\hline Lepidoptera & 0.00 & 0.00 & 0.00 & 0.00 & 0.22 & 0.12 & 0.00 & 0.00 \\
\hline Megaloptera & 0.00 & 0.00 & 0.00 & 0.00 & 0.00 & 0.01 & 0.00 & 0.03 \\
\hline Odonata & 0.38 & 0.06 & 0.00 & 0.07 & 0.00 & 0.01 & 0.60 & 0.30 \\
\hline Plecoptera & 0.00 & 0.00 & 1.34 & 3.19 & 0.18 & 0.08 & 0.60 & 0.68 \\
\hline Trichoptera & 3.65 & 5.26 & 5.36 & 5.07 & 24.25 & 25.96 & 6.04 & 5.45 \\
\hline \multicolumn{9}{|l|}{ TOTAL OTU's (82) } \\
\hline Total abundance & 2002 & 2358 & 1064 & 2136 & 2800 & 9255 & 1077 & 3612 \\
\hline Relative abundance & 45.92 & 54.08 & 33.25 & 66.75 & 23.23 & 76.77 & 22.97 & 77.03 \\
\hline Richness & 39 & 36 & 37 & 41 & 29 & 42 & 42 & 56 \\
\hline \% OTU's rare & 64.10 & 61.11 & 62.16 & 63.41 & 58.62 & 64.29 & 69.05 & 76.79 \\
\hline
\end{tabular}


Table 2. Relative abundance (\%) of benthic invertebrates sampled in two reaches of Farias stream (O- open, F- forest) in 2014 and 2015, using two samplers (Surber and D-frame net). Data presented for the higher taxonomic groups, for the Hexapoda orders and for the total OTU's sampled (rare = abundance $<1 \%$ ).

\begin{tabular}{|c|c|c|c|c|c|c|c|c|}
\hline \multirow{2}{*}{ HIGHER GROUPS } & \multicolumn{2}{|c|}{ O-2014 } & \multicolumn{2}{|c|}{$0-2015$} & \multicolumn{2}{|c|}{ F-2014 } & \multicolumn{2}{|c|}{ F-2015 } \\
\hline & Surber & D-frame & Surber & D-frame & Surber & D-frame & Surber & D-frame \\
\hline Cnidaria & 0.00 & 0.00 & 0.09 & 0.00 & 0.00 & 0.00 & 0.00 & 0.00 \\
\hline Platyhelminthes & 0.07 & 0.00 & 0.09 & 0.04 & 0.00 & 0.00 & 0.00 & 0.00 \\
\hline Nemertea & 0.07 & 0.10 & 0.09 & 0.07 & 0.00 & 2.03 & 0.73 & 0.00 \\
\hline Mollusca & 0.74 & 1.16 & 0.61 & 0.70 & 10.00 & 10.14 & 32.85 & 36.11 \\
\hline Annelida & 2.08 & 0.68 & 2.68 & 4.08 & 31.54 & 24.32 & 21.17 & 5.66 \\
\hline Nematoda & 0.00 & 0.00 & 0.43 & 0.00 & 0.77 & 0.00 & 0.73 & 0.00 \\
\hline Chelicerata & 1.86 & 1.16 & 0.35 & 0.30 & 5.38 & 3.38 & 0.00 & 0.67 \\
\hline Crustacea & 0.37 & 0.82 & 0.26 & 0.11 & 3.08 & 2.03 & 3.65 & 2.50 \\
\hline Hexapoda & 94.79 & 96.09 & 95.42 & 94.70 & 49.23 & 58.11 & 40.88 & 55.07 \\
\hline \multicolumn{9}{|l|}{ HEXAPODA ORDERS } \\
\hline Collembola & 0.47 & 0.20 & 0.54 & 0.16 & 0.00 & 1.16 & 1.79 & 0.60 \\
\hline Coleoptera & 11.07 & 5.89 & 10.24 & 11.59 & 9.38 & 11.63 & 3.57 & 4.23 \\
\hline Diptera & 52.75 & 57.44 & 52.72 & 57.44 & 60.94 & 68.60 & 69.64 & 81.27 \\
\hline Ephemeroptera & 30.53 & 28.77 & 23.46 & 19.54 & 29.69 & 13.95 & 12.50 & 9.06 \\
\hline Hemiptera & 0.08 & 0.05 & 0.09 & 0.04 & 0.00 & 0.00 & 1.79 & 0.00 \\
\hline Lepidoptera & 0.00 & 0.00 & 0.00 & 0.08 & 0.00 & 0.00 & 1.79 & 0.30 \\
\hline Odonata & 0.08 & 0.86 & 0.72 & 0.82 & 0.00 & 2.33 & 0.00 & 0.91 \\
\hline Trichoptera & 5.02 & 6.79 & 12.23 & 10.34 & 0.00 & 2.33 & 8.93 & 3.63 \\
\hline \multicolumn{9}{|l|}{ TOTAL OTU's (54) } \\
\hline Total abundance & 1344 & 2069 & 1157 & 2697 & 130 & 148 & 137 & 601 \\
\hline Relative abundance & 39.38 & 60.62 & 30.02 & 69.98 & 46.76 & 53.24 & 18.56 & 81.44 \\
\hline Richness & 23 & 31 & 33 & 29 & 19 & 18 & 21 & 28 \\
\hline \% OTU's rare & 56.52 & 74.19 & 72.73 & 68.97 & 36.84 & 22.22 & 47.62 & 60.71 \\
\hline
\end{tabular}

represented mainly by the orders Diptera and Ephemeroptera (Table 1). In that stream, it is also possible to highlight the high percentage of Annelida (open reach in 2015) and Trichoptera (forest reach in 2014).

The two samplers also responded in a similar way to the analysis of invertebrate groups collected in Farias stream. The results showed a predominance of Hexapoda in all cases analyzed, mainly of the orders Diptera and Ephemeroptera, and a high relative abundance of Mollusca (Bivalvia) and Annelida (Oligochaeta) in the forest reach (Table 2).

The Hierarchical Clustering analysis and Principal Coordinates analysis applied to the abundance data reinforced the high similarity in the response of the two samplers for both streams. For Itaúna stream, the cluster (Figure 3A) grouped the Surber and D-frame with high values of similarity for both reaches and years. The two axis of the PCO explained $68.2 \%$ of total data variation (Figure 3B), approaching the samplers of the same reach/year, the PCO1 separating the reaches and $\mathrm{PCO} 2$ the years in opposite sides. For Farias stream, the cluster (Figure 4A) grouped the Surber and D-frame with high values of similarity for both

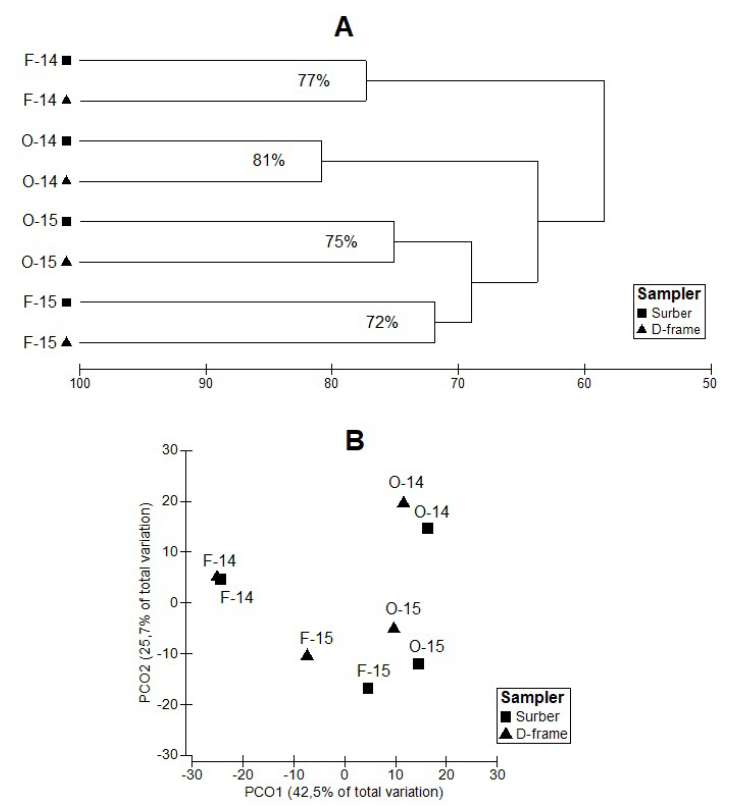

Figure 3. Results of the Hierarchical Clustering analysis (A, with the percentage of similarity grouping the samplers) and Principal Coordinates analysis (B) constructed with data of total OTU's sampled with Surber and D-frame net in reaches of Itaúna stream with (F-forest) and without (O-open) riparian vegetation, in 2014 and 2015. 

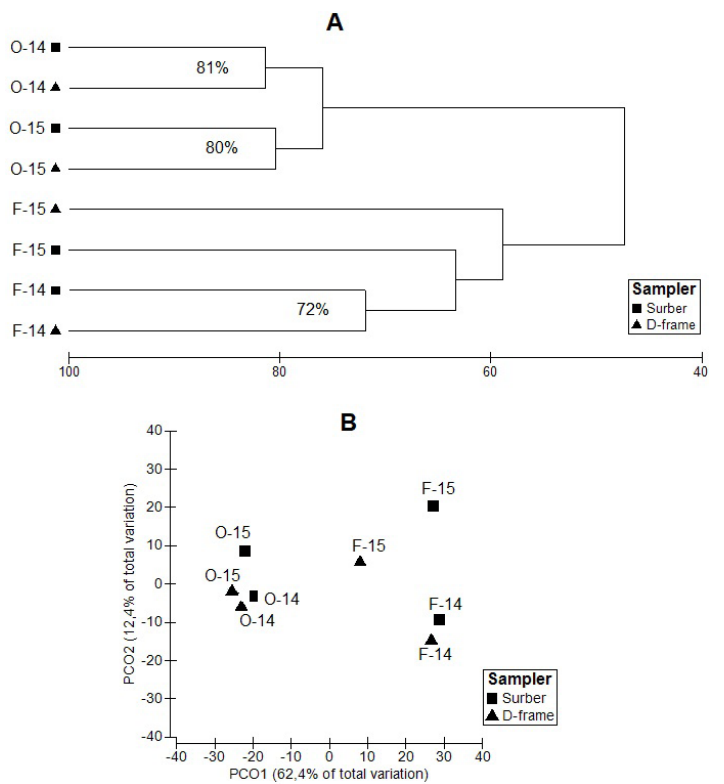

Figure 4. Results of the Hierarchical Clustering analysis (A, with the percentage of similarity grouping the samplers) and Principal Coordinates analysis (B) constructed with data of total OTU's sampled with Surber and D-frame net in reaches of Farias stream with (F-forest) and without (O-open) riparian vegetation, in 2014 and 2015.

years of open reach and for forest-2014 samples. The two axis of the PCO explained $74.8 \%$ of total data variation (Figure 4B), approaching the samplers of the same reach/year, the PCO1 separating the reaches and $\mathrm{PCO} 2$ the years in opposite sides.

\section{Discussion}

In biological monitoring, the selection of the sampler is one of the issues that may influence the conclusions of the study, since together with the processing of the samples and metrics to be applied it can lead to significantly different results (Carter \& Resh, 2001; Buss \& Borges, 2008). Sampling methods used in biomonitoring programs should address issues such as cost-effectiveness, the time spent in sampling and sorting as a measure of cost, and richness as a measure of effectiveness (Buss \& Borges, 2008). Although the choice of the best methodology is still widely discussed in the literature, the D-frame net has been recommended and preferred in several countries (Storey et al., 1991; Buss \& Borges, 2008), allowing the collection of high taxa richness and providing accurate indexes (Buss \& Borges, 2008; Hughes \& Peck, 2008).

Both samplers are low cost and easy to use, although some peculiarities are inherent to each of these two methodologies: the Surber sampler can be handled by only one person, the $\mathrm{D}$-frame net needs two person but can be used at depths higher than $30 \mathrm{~cm}$ (Buss \& Borges, 2008).

In the present work, a high similarity in the response of the two samplers occurred even considering the occurrence of spatial (differences between streams and reaches) and temporal variation (two years). In terms of cost-effectiveness and biological conservation, the Surber proved to be more advantageous for having the same effectiveness of $\mathrm{D}$-frame net in analyzing the fauna structure, but sampling a much smaller number of individuals.

The samplers also give the same results about the assemblage composition when considered the types of substrate in the streams and reaches. The greater richness of taxa in Itaúna stream can be related to the rocky substrate, as the heterogeneity of this substrate offers greater complexity and stability, stimulating the fauna diversity and abundance (Kikuchi \& Uieda, 2005). On the other hand, the sandy-clay substrate found in Farias stream can be related to the presence of tolerant groups like Oligochaeta and Bivalvia, frequently abundant in this unstable substrate that offers little availability of food and difficult of anchorage for several invertebrates (Kikuchi \& Uieda, 2005).

The similarity between samplers also persisted in relation to temporal variations. Seasonal variations in the habitat structure may also influence the pattern of invertebrate distribution, as the increase in rainfall can make it difficult for the individuals to remain in the substrate, due to increase in the speed of the current and consequent drag (Kikuchi \& Uieda, 2005; Bispo et al., 2006; Carvalho et al., 2008). The leaching process caused by the higher rainfall in 2015 drag sediment to the channel and could favored an increase in Oligochaeta abundance in the Itaúna stream, as these invertebrates are generally associated to the fine sediment deposited in the rocky bed. On the other hand, the low rainfall in 2014 may have favored an increase in the abundance of Simuliidae, whose larvae use the rocky substrate while filtering food carried by the current (Kikuchi \& Uieda, 2005).

Different types of anthropic impacts, such as total or partial removal of riparian vegetation, can cause a decrease in water quality and change in the invertebrate distribution pattern (Roth et al., 1996; Yoshida \& Rolla, 2012), based on the sensitivity and tolerance of each taxon to stress factors (Mugnai et al., 2011; Yoshida \& Rolla, 2012). Both samplers were effective in the search 
of those groups. Although Ephemeroptera is considered a group susceptible to environmental disturbances, it can colonize a variety of habitats, such as running water, rocky and sandy bottoms with litter accumulation (Salles et al., 2004; Bispo et al., 2006; Bagatini et al., 2012). This versatility of the group may explain the high abundance of the mayfly genus Traverhyphes in two quite different streams and reaches studied. The higher abundance of Traverhyphes in the forest reach of Itaúna stream may be related to the occurrence of this group in rocky bottom streams, with vegetal debris and semi-deciduous riparian vegetation, a situation also observed by Kikuchi \& Uieda (2005) and Siegloch et al. (2014). On the other hand, high abundance of Traverhyphes also occurred in the open reach of Farias stream, where a dense bank of macrophytes covers the sandy-clay substrate. This aquatic vegetation contributes with an increase in the complexity and heterogeneity of the habitat, serving as shelter and feeding place for a diverse fauna (Thomaz \& Cunha, 2010).

In the present study, the position of the reaches with and without riparian vegetation also influenced the spatial analysis for both samplers. In Itaúna stream, the open reach receives the input of organic material and vegetable debris carried from the forest reach located upstream, and this material adheres to the marginal and submerged grass offering shelter and food and contributing to the high richness and abundance of invertebrates. For Farias stream, the sand and clay transported from the open reach deposits on the gravel substrate of the forest reach located downstream, reducing the availability of resources and habitat quality, and, consequently, the richness and abundance of invertebrates.

In summary, the two samplers were equally effective in analyzing the benthic invertebrates and sensitive enough to point to a spatial and temporal variation in the structure of this fauna, influenced by the presence of riparian vegetation, by type of substrate and position of the forest reach. The Surber and D-frame net are easy to handle in lotic environments, in rocky or sandy substrate, sampling litter or macrophyte, allowing qualitative and quantitative analysis of the fauna. Nevertheless, we consider the use of Surber more advantageous because it samples less individuals, reducing the time of processing and identifying in the laboratory (low cost and high effectiveness), and allows a more precise definition of the area sampled.

\section{Acknowledgements}

To Ana Liz U. Melo, Pedro S. Manoel, Fernando P. R. Arruda, Sílvio C. Almeida and Hamilton A. Rodrigues for assistance in field work.

\section{References}

BAGATINI, Y.M., DELARIVA, R.L. and HIGUTI, J. Benthic macroinvertebrate community structure in a stream of the north-west region of Paraná State, Brazil. Biota Neotropica, 2012, 12(1), 307-317. http:// dx.doi.org/10.1590/S1676-06032012000100023.

BISPO, P.C., OLIVEIRA, L.G., BINI, L.M. and SOUSA, K.G. Ephemeroptera, Plecoptera and Trichoptera assemblages from riffles in mountain streams of central Brazil: environmental factors influencing the distribution and abundance of immatures. Brazilian Journal of Biology $=$ Revista Brasileira de Biologia, 2006, 66(2B), 611-622. http:// dx.doi.org/10.1590/S1519-69842006000400005. PMid:16906293.

BUSS, D.F., BAPTISTA, D.F. and NESSIMIAN, J.L. Bases conceituais para a aplicação de biomonitoramento em programas de avaliação da qualidade da água de rios. Cadernos de Saude Publica, 2003, 19(2), 465-473. http://dx.doi.org/10.1590/ S0102-311X2003000200013. PMid:12764462.

BUSS, D.F. and BORGES, E.L. Application of rapid bioassessment protocols (RBP) for benthic macroinvertebrates in Brazil: comparison between sampling techniques and mesh sizes. Neotropical Entomology, 2008, 37(3), 288-295. http://dx.doi. org/10.1590/S1519-566X2008000300007. PMid:18641899.

BUSS, D.F., CARLISLE, D.M., CHON, T.S., CULP, J., HARDING, J.S., KEIZER-VLEK, H.E., ROBINSON, W.A., STRACHAN, S., THIRION, C. and HUGHES, R.M. Stream biomonitoring using macroinvertebrates around the globe: a comparison of large-scale programs. Environmental Monitoring and Assessment, 2015, 187(1), 4132. http://dx.doi. org/10.1007/s10661-014-4132-8. PMid:25487459.

CALLANAN, M., BAARS, J.-R. and KELLY-QUINN, $M$. Critical influence of seasonal sampling on the ecological quality assessment of small headwater streams. Hydrobiologia, 2008, 610(1), 245-255. http://dx.doi.org/10.1007/s10750-008-9439-4.

CARTER, J.L. and RESH, V.H. After site selection and before data analysis: sampling, sorting, and laboratory procedures used in stream benthic macroinvertebrate monitoring programs by USA state agencies. Journal of the North American Benthological Society, 2001, 20(4), 658-682. http://dx.doi.org/10.2307/1468095.

CARVALHO, E.M., UIEDA, V.S. and MOTTA, R.L. Colonization of rocky and leaf pack substrates by benthic macroinvertebrates in a stream in Southeast Brazil. Bioikos (Campinas), 2008, 22(1), 37-44. 
DOMÍNGUEZ, E. and FERNÁNDEZ, H.R. Macroinvertebrados bentônicos sudamericanos: sistemática y biologia. Tucumán: Fundación Miguel Lillo, 2009.

HUGHES, R.M. and PECK, D.V. Acquiring data for large aquatic resource surveys: the art of compromise among science, logistics, and reality. Journal of the North American Benthological Society, 2008, 27(4), 837-859. http://dx.doi.org/10.1899/08-028.1.

KIKUCHI, R.M. and UIEDA, V.S. Composição e distribuiçáo dos macroinvertebrados em diferentes substratos de fundo de um riacho no município de Itatinga, São Paulo, Brasil. Entomología y Vectores, 2005, 12(2), 193-231. http://dx.doi.org/10.1590/ S0328-03812005000200006.

KUHLMANN, M.L., JOHNSCHER-FORNASARO, G., OGURA, L.L. and IMBIMBO, H.R.V. Protocolo para o biomonitoramento com as comunidades bentônicas de rios e reservatórios do estado de São Paulo. São Paulo: CETESB, 2012.

MUGNAI, R., BUSS, D.F., OLIVEIRA, R.B., SANFINS, C., CARVALHO, A.L. and BAPTISTA, D.F. Application of the biotic index IBE-IOC for water quality assessment in wadeable streams in south-east Brazil. Acta Limnologica Brasiliensia, 2011, 23(1), 74-85. http://dx.doi.org/10.4322/ actalb.2011.021.

MUGNAI, R., NESSIMIAN, J.L. and BAPTISTA, D.F. Manual de identificação de macroinvertebrados aquáticos do Estado do Rio de Janeiro. Rio de Janeiro: Technical Books Editora, 2010.

PENNAK, R.W. Freshwater invertebrates of the United States. New York: Jonh Wiley \& Sons, 1978.

ROTH, N.E., ALLAN, J.D. and ERICKSON, D.L. Landscape influences on stream biotic integrity assessed at multiple spatial scales. Landscape Ecology,
1996, 11(3), 141-156. http://dx.doi.org/10.1007/ BF02447513.

SALLES, F.F., DA-SILVA, E.R., HUBBARD, M.D. and SERRÃO, J.E. As espécies de Ephemeroptera (Insecta) registradas para o Brasil. Biota Neotropica, 2004, 4(2), 1.

SIEGLOCH, A.E., SURIANO, M., SPIES, M. and FONSECA-GESSNER, A. Effect of land use on mayfly assemblages structure in Neotropical headwater streams. Anais da Academia Brasileira de Ciências, 2014, 86(4), 1735-1747. http:// dx.doi.org/10.1590/0001-3765201420130516. PMid:25590712.

STOREY, A.W., EDWARD, D.H.D. and GAZEY, P. Surber and kick sampling: a comparison for the assessment of macroinvertebrate community structure in streams of south-western Australia. Hydrobiologia, 1991, 211(2), 111-121. http://dx.doi. org/10.1007/BF00037367.

THOMAZ, S.M. and CUNHA, E.R. The role of macrophytes in habitat structuring in aquatic ecosystems: methods of measurement, causes and consequences on animal assemblages' composition and biodiversity. Acta Limnologica Brasiliensia, 2010, 22(2), 218-236. http://dx.doi.org/10.4322/ actalb.02202011.

YOSHIDA, C.E. and ROLLA, A.P.P.R. Ecological attributes of the benthic community and indices of water quality in urban, rural and preserved environments. Acta Limnologica Brasiliensia, 2012, 24(3), 235-243. http://dx.doi.org/10.1590/S2179975X2012005000041.

Received: 05 April 2017 Accepted: 18 December 2018 